\title{
CHANGES IN THE ACTIVE POPULATION STRUCTURE OF PETROŞANI DEPRESSION
}

\author{
Gabriela-Alina MUREȘAN \\ Babeș-Bolyai University, Faculty of Geography, Clinicilor Street, Nr. 5-7, RO- 400006, Cluj-Napoca, \\ Romania, e-mail: alina.muresan@ubbcluj.ro
}

Mădălin-Sebastian LUNG *

Ph.D. Student, Babeș-Bolyai University, Faculty of Geography, Clinicilor Street, Nr. 5-7, RO- 400006, Cluj-Napoca, Romania, e-mail: 1ungmadalin@yahoo.com

Citation: Mureșan, G.-A., Lung, M.-S. (2019). Changes in the Active Population Structure of Petroşani Depression. Revista Română de Geografie Politică, 21(2), 60-67. https://doi.org/10.30892/rrgp.212104-332

\begin{abstract}
Numerous sociological and geographic studies insist on the consequences of industrial restructuring on the mining regions of Romania, in particular Petroşani Depression. The most widely known effects were social in nature, especially high unemployment rates. However, the demographic consequences of such a process are equally important, with visible short, medium, and long-time effects: emmigration, low birth rates, population decrease, changes in the demographic structure. Our paper intends to analyze the changes that took place within the occupational structure of the area in the last 27 years, caused by mine closings and massive worker layoffs. Despite the fact that the industrial sector, once the defining feature of the region, has been in continuous decline, it continues to employ a significant portion of the occupied population in the region. Overall however, according to statistical data, mining operations and activities are waning.
\end{abstract}

Key words: economic restructuring, mining industry, active population, Petroşani Depression

\section{INTRODUCTION}

Petroşani Depression is the most important coal producing area of Romania. The coal deposits in the area had been known since the second half of the $18^{\text {th }}$ century. Mining operations, however, began in the second half of the $19^{\text {th }}$ century, growing alongside the development of the transport infrastructure, culminating in the mining industry of the communist period (Costache and Pehoiu, 2010). During this period, coal mining intensified in order to meet the energy needs of the ever 
growing communist industry, but also in order to insure a complete energy and mineral resource independence, thus significantly reducing imports.

The extensive development of mining in the second half of the $20^{\text {th }}$ century created a mono-industrial area, which eventually led to complex problems after 1990, with the regime change and the beginning of the transition towards a market economy. Economic liberalization required a restructuring of all inefficient economic sectors. This was a nationwide and the most affected regions were the predominantly industrialized ones (Iancu, 2007).

Mining also required reorganisation and closure of nonprofitable mines as well as the usage of new technologies for the still viable ones (Neagu et al., 2015). In Romania, mining is difficult and production costs are extremely high, therefore the Romanian state sustained mining operations through budget allocations aimed at investments and subsidies (Schmidt and Andrioni, 2011). In Petroşani Depression, pitcoal deposits are mostly located in geological strata that are arduous to mine. Moreover, they produce a low heat yield, which implies high mining costs (Neagu et al., 2015).

Mining restructuring involved several actions, but was extensively based on staff layoffs. In the region of Valea Jiului (another name of the coalfield Petrosani), this process started in 1997, after Ordinance nr. 22/1997 triggered the sacking of almost half of the entire population of miners. According to the data provided by the Hunedoara Energy Complex $(\mathrm{CEH}), 18185$ people were laid off that year, with further, smaller scale, layoffs the following years. In total, between 1997 and 2018, almost 29400 people lost their jobs.

The geographic area of Petroşani Depression has been a diversified framework for the emergence and diversification of many socio-demographic phenomena that have taken place and are still raising interest for researchers (Andrioni, 2017; Mureșan and Lazăr, 2017). A study similar to the one we wanted was made for the mental space of The Land of Moți from Apuseni Mountains (Mureșan and Boțan, 2015).

The coal mining and processing industry, namely the negative influences related to this industry, have entered the research field of scientists around the world (Simmons, 1976; Binns and Nel, 2003; Ivanova, Rolfe, Lockie, Timmer, 2007; Rolfe, Miles, Lockie, Ivanova, 2007; Fatah, 2008; Hendryx and Ahern, 2009; Franks, Brereton, Moran, 2010; Zafrilla, 2014; Kowalska, 2015; Vácha, Skála, Čechmánková, Horváthová, Hladík, 2015; Crețu et al., 2013).

The mining restructuring process had a series of social, demographic, economic, and environmental consequences. The most widely spread and analyzed effect was the rise of the unemployment rate.

This paper aims to analyze one of the most important consequences restructuring has had on the community, which is tightly linked to the spike in unemployment: changes in the active population structure. There are other demographic phenomena which have impacted the area following the restructuring process, but we will deal with those in another paper (migration, low birth rates, population loss). The area of the Petrosani depression has been studied from various perspectives, but most studies have targeted the social state of the demographic component. Through our study we wanted to achieve a prognosis and diagnosis on the evolution of the occupational structure at every census after the end of the etatiste period. If, by 1989, the population of active depression in the mining industry, with the beginning of capitalism followed extensive restructuring of the Carboniferous industry. The share of the active 
population in the depression began to decline steadily after 1989, in the same trend being the secondary sector, with increasing weights from one census to another. Instead, the tertiary sector weights began to grow, more and more population activating in services. However, the service sector has yet to fully absorb the redundant personnel from mining, areas such as manufacturing and construction being continuously growing.

\section{RESEARCH METHODOLOGY}

Statistical data from the census of years 1992 (NIS), 2002 (NIS) and 2011 (NIS) were used to achieve this study. The data was processed through the Microsoft Excel 2013 program, and a number of figures were generated. Thus, a figure was made for the evolution of the share of the active population, in three other figures there was the evolution of the occupational structure by economic sectors, respectively three figures were generated on the evolution of the number of employees the main economic areas of depression.

\section{CHANGES IN THE OCCUPATIONAL STRUCTURE OF PETROŞANI DEPRESSION}

To emphasize said changes, as direct effects of the mining restructuring process, we analyzed the seven towns and communes that comprise the area: Petroşani, Aninoasa, Lupeni, Petrila, Uricani, Vulcan, and Bănița. We processed data from the last three national censuses: 1992, 2002 and 2011. There are several differences between censuses in terms of population categories: in 1992 and 2002, the population distribution per economic activities was done based on the active population (also including "unemployed in search of first place of work"), while in 2011, the Household and Population Census used only the occupied population (excludes the unemployed category).

The active/occupied population in the main activity sectors represents a clear indicator of the economic specificity of the region, mostly based on mining and mono-industry. Firstly, according to data, there is a continuous decrease in active population from census to census: in 1992, it represented $42.6 \%$ of the total population, in 2002 dropping to $36.7 \%$, while in 2011 descending to $34.4 \%$ (figure 1 ).

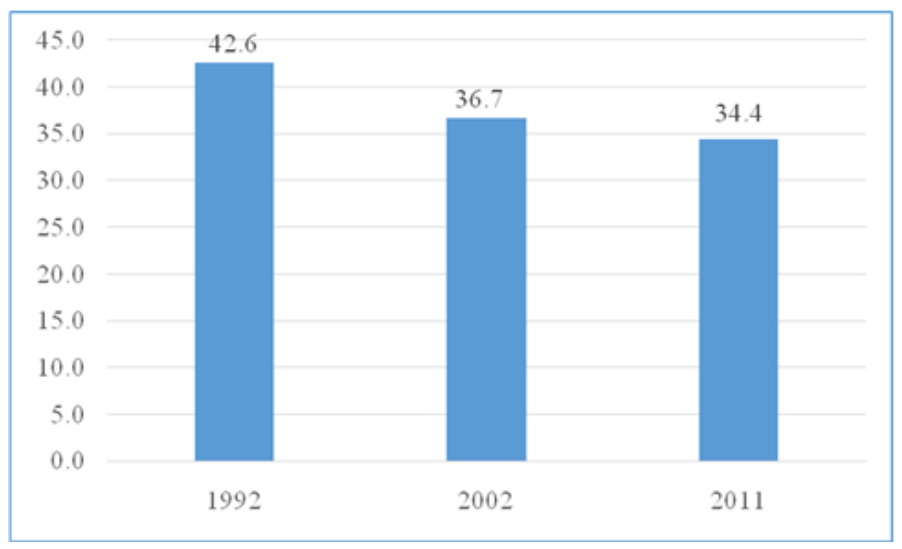

Figure 1. Percentage of the active/employed population in Petroşani Depression (1992, 2002, 2011)

(Source: data processed after the 1992, 2002, 2011 Censuses) 
The most significant decrease occured between 1992-2002, strongly correlated with the layoffs that began in 1997. At administrative-territorial level, if in 1992, almost all settlements exceeded the 40\% threshold (with two exceptions: Aninoasa and Bănița), ten years later, none reached said percentage. Until 2011, the active population continued to drop, with the exception of Bănița Commune, where it reached over 55\% (mostly due to an increase in people working in the primary sector).

The economically active population is generally divided into three groups, based on the economic sectors: primary, secondary and tertiary. The most representative sector for the Petrossani Depression, in all three years under scrutiny, was, in accordance with the specificity of the region, the secondary sector. However, the numbers differ from year to year, being in constant decrease. At the 1992 Census, the secondary sector held $72.2 \%$ of the economically active population. This average value is topped in almost every settlement, except Petroşani (62.2\%) and Bănița (43.8\%). The workforce employed in the mining industry is almost half $(48 \%)$ of the active population in the region, and two thirds $(66.8 \%)$ of the one employed in the secondary sector. The primary sector held only $1 \%$, while the service industry $23.7 \%$ of the population (figure 2). Rural areas (Bănița Commune) are also surprinsingly non-agricultural, with solely $3.1 \%$ of the active population working in agriculture.

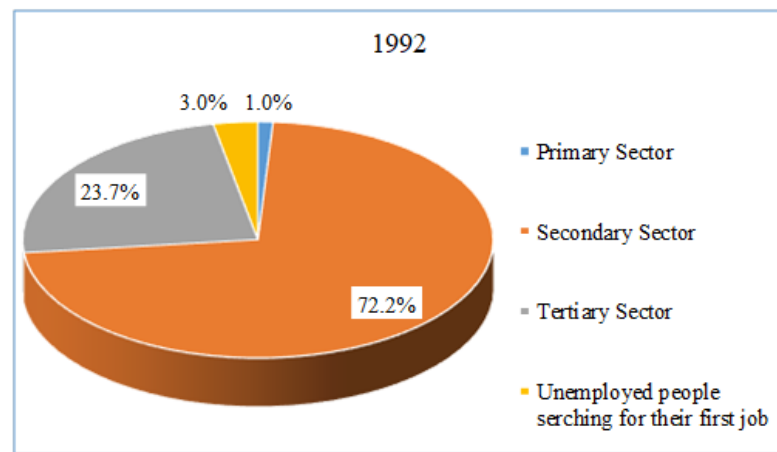

Figure 2. Occupational structure of Petroşani Depression in 1992 (Source: data processed after the 1992 Census)

A particular category registered at the first two censuses are the unemployed people searching for their first job; in 1992, their percentage reached $3 \%$.

The 2002 data however show the changes taking place in the national economy. As previously shown, the mining restructuring process commenced in 1997, and at the 2002 Census, researchers registered a significant decrease of the active population employed in the secondary sector, by 14 percentage points, reaching $58.2 \%$. Despite this, the mining population continued to register almost two thirds of the secondary sector $(65.3 \%)$. Compared to the entire economy of the region, it represented 38\% of the active population. Similarly to 1992, the city of Petroşani and the commune of Bănița are below the region's average. The cultural function held by Petroşani (a university center which, after 1990, diversified its fields of study), as well as other tertiary functions, explain these lower values of secondary active population. The primary sector remained unchanged from 1992 (1\%), while the active population employed in the tertiary 
sector reached $32.6 \%$ (figure 3 ). The unemployed in search of first job are more numerous $(8.2 \%)$, compared to the situation registered in 1992.

In 2011 , the secondary sector remained dominant, registering $47 \%$ of the entire occupied population; however, all administrative-territorial units lost more than half of their secondary workers. Furthermore, the percentage of miners decreased to just $19 \%$ of the total occupied population, and $40.4 \%$ of the total secondary population (decrease of 20.5 percentage points compared to 2002). Thusly, the number of employees working in the mining industry declined by $3 / 4$ between 1992 and 2011. The occupied population in the primary sector increased by $6.9 \%$. This is due to the urban-rural migration, but also to the return to more traditional activities (agriculture, logging), as other work opportunities dried out; in the commune of Bănița, the number of people working in the primary sector increased in 2011 compared to 2002 by more than $80 \%$. Significant increases were also registered in towns (Aninoasa, by 95\%). The tertiary sector was the most dynamic, mostly in the urban areas of the region, a characteristic that defined Romanian towns and cities during the transition period (in 2011, people working in the service industry reached $46.1 \%$, equal to secondary sector workers) (figure 4).

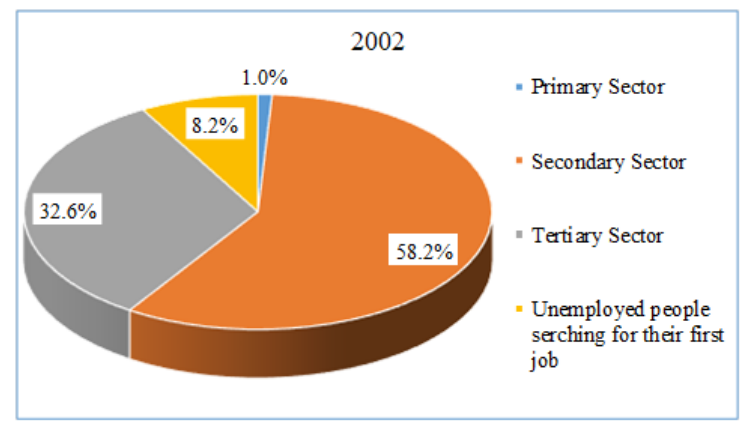

Figure 3. Occupational structure of Petroşani Depression in 2002 (Source: data processed after the 2002 Census)

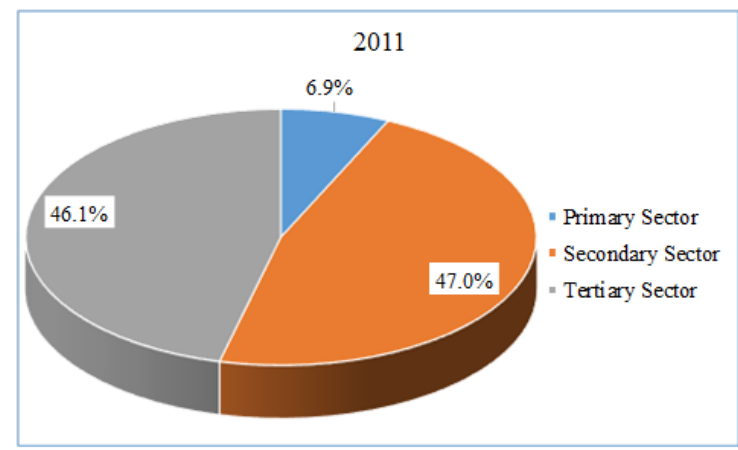

Figure 4. Occupational structure of Petroşani Depression in 2011 (Source: data processed after the 2011 Census)

The following graphs (figures 5, 6, 7) emphasize the dominance played by mining in the region's economy, but also its downward trend registered from 1992 onwards, in terms of employees. The sector decreased by almost 80\% (from 34674 people in 1992 to 7955 in 2011). 


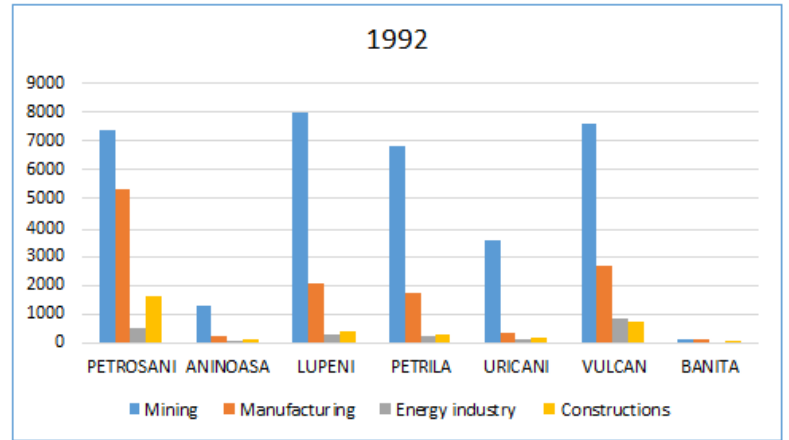

Figure 5. Number of industrial sector employees in Petroşani Depression (1992) (Source: data processed after the 1992 Census)

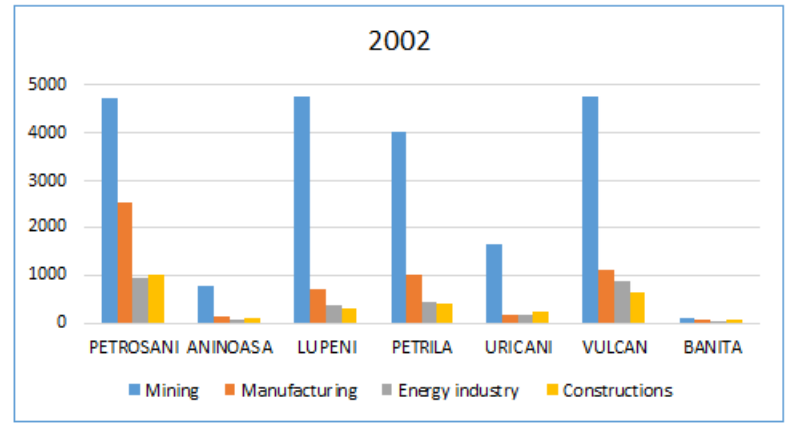

Figure 6. Number of industrial sector employees in Petroşani Depression (2002) (Source: data processed after the 2002 Census)

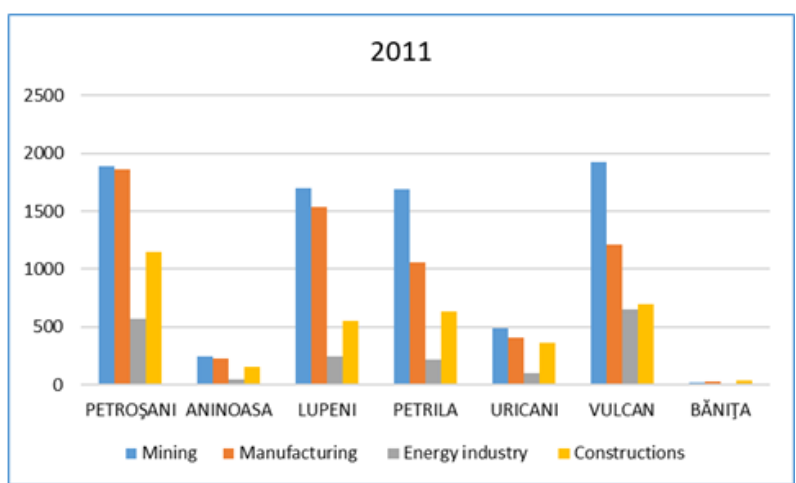

Figure 7. Number of industrial sector employees in Petroşani Depression (2011) (Source: data processed after the 2011 Census)

\section{CONCLUSIONS}

The analysis of the economically active population structure of the Petrossani area emphasizes the mono-industrial characteristic that defined the region for the last decades. It constitutes a communist inheritance, which eventually led to a supersized mining industry. As Romania transitioned to a market economy, an economic restructuring was put into effect, which primarily impacted the industrial sector and the mining industry. The region faced a reduction in active 
population, a phenomenon visible starting from the 1992 Census. Despite the fact that the industrial sector lost almost 25 percentage points between 1992 and 2011, it still remains a rather strong sector. It has been equaled by tertiary activities in the past few years. Mining subsided as mines closed and a significant number of employees had been laid off. The population working in the mining industry decreased by almost 80\% between 1992 and 2011. The remaining economic sectors could not absorb the entire jobless population, despite being on the rise. This created high unemployment rates, social conflicts, increased emmigration, and, finally, a poor economic dynamic in the region.

\section{REFERENCES}

Andrioni, F. (2017). Social-Economic Influences of Mining Syncopes in the Jiu Valley over the Members of the Community. Annals of the University of Petroşani, Mining Engineering, 18, 178-189.

Binns, T., \& Nel, E. (2003). The Village in a Game Park: Local Response to the Demise of Coal Mining in KwaZulu-Natal, South Africa. Economic Geography, 79(1), 41-66.

Costache, A., \& Pehoiu, G. (2010). Social and Economic Effects of Mining Industry Restructuring in Romania - Case Studies, World Academy of Science. Engineering and Technology, International Journal of Social, Behavioral, Educational, Economic, Business and Industrial Engineering 4(6), 873-877.

Crețu, C., Herman, G. V., \& Ile, M. (2013). The Impact of the Mining Exploitations from Budoi on the Natural Environment. Analele Universității din Oradea, Seria Geografie, 23(1), 73-79.

Fatah, L. (2008). The Impacts of Coal Mining on the Economy and Environment of South Kalimantan Province, Indonesia. ASEAN Economic Bulletin, 25(1), 85-98.

Franks, D. M., Brereton, D., \& Moran, C. J. (2010). Managing the cumulative impacts of coal mining on regional communities and environments in Australia. Impact Assessment and Project Appraisal, 28(4), 299-312. https://doi.org/10.3152/146155110X12838715793129

Hendryx, M., \& Ahern, M.M. (2009). Mortality in Appalachian Coal Mining Regions: The Value of Statistical Life Lost. Public Health Reports, 124(4), 541-550. https:/ / doi.org/10.1177/003335490912400411

Iancu, F-C. (2007). The Economic, Social, Demographic and Environmental Effects of the Economic Reorganization within Petroşani Depression. Analele Universității din Craiova, Seria Geografie, 10, 127-135.

Ivanova, G., Rolfe, J., Lockie, S., \& Timmer, V. (2007). Assessing social and economic impacts associated with changes in the coal mining industry in the Bowen Basin, Queensland, Australia. Management of Environmental Quality, 18(2), 211-228. https:/ / doi.org/10.1108/14777830710725867

Kowalska, I. J. (2015). Challenges for long-term industry restructuring in the Upper Silesian Coal Basin: What has Polish coal mining achieved and failed from a twenty-year perspective?, Resources Policy, 44, 135-149. https://doi.org/10.1016/j.resourpol.2015.02.009

Ministerul Economiei, Comerțului şi Relațiilor cu Mediul de Afaceri (2016). Strategia minieră a României 2017 - 2035, available at http://www.economie.gov.ro/images/resurseminerale/STRATEGIE\%20MINIERA\%20draft\%20final\%2024\%200CT\%202016.pdf.

Mureşan, G-A., \& Boțan, C-N. (2015). The Socio-Occupational Structure of the Population in the Apuseni Mountains.Case Study: the Land of the Moti. Romanian Review of Regional Studies, $11(2), 49-56$.

Mureşan, G-A., \& Lazăr, A-D. (2017). Geodemographic Risks in Petroşani Basin (I). Studia Universitatis Babeş-Bolyai, Geographia, 62(2), 33-48.

Neagu, C., Bulearcă, M., Sima, C., \& Mărguş, D. (2015). A SWOT analysis of Romanian Extractive Industry and Re-Industrialization Requirements of This Industry. $2^{\text {nd }}$ International Conference 'Economic Scientific Research - Theoretical, Empirical and Practical Approaches', ESPERA 2014, 13-14 November 2014, Bucharest, Romania, Procedia Economics and Finance 22, p. $287-295$.

Rolfe, J., Miles, B., Lockie, S., \& Ivanova, G. (2007). Lessons from the Social and Economic Impacts of the Mining Boom in the Bowen Basin 2004-2006. Australasian Journal of Regional Studies, 13(2), 134-153. 
Schmidt, M. C., \& Andrioni, F. (2011). Restructuring and Reform in the Jiu Valley. Annals of the University of Petroşani, Economics, 11(1), 235-244.

Simmons, C.P. (1976). Recruiting and Organizing an Industrial Labour Force in Colonial India: The Case of the Coal Mining Industry, c. 1880-1939. The Indian Economic \& Social History Review, 13(4), 455.485. https://doi.org/10.1177/001946467601300402

Vácha, R., Skála, J., Čechmánková, J., Horváthová, V., \& Hladík, J. (2015). Toxic elements and persistent organic pollutants derived from industrial emissions in agricultural soils of the Northern Czech Republic. Journal of Soils and Sediments, 15(8), 1813-1824. https://doi.org/10.1007/s11368-015-1120-8

Zafrilla, J.E. (2014). The mining industry under the thumb of politicians: the environmental consequences of the Spanish Coal Decree. Journal of Cleaner Production, 84, 715-722. https://doi.org/10.1016/j.jclepro.2014.02.031

*** (2008). Strategia industriei miniere pentru perioada 2008-2020, available at http://www.minind.ro/strateg_miniera/Strategia_2008-2020_02062008.pdf.

*** Population and housing Censuses from 1992, 2002, 2011.

Submitted:

July 22, 2019
Revised:

September 20, 2019
Accepted and published online: November 27, 2019 